\title{
尿成分ヨリ觀タル膠質銀ノ新陳代謝 二及ボス影葲二就キテノ知見補遺
}

\author{
束京帝國大學傳染病研究所 \\ 生物化學室(主任河本教授)
}

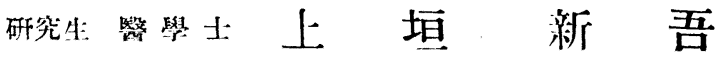

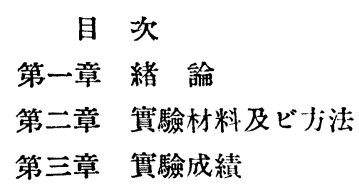

目 次

第二章 實驗材料及ビ少法

第三章＼cjkstart賽驗成績

\section{第一章 緒 論}

余ハ暴キ二膠質銀，有スル殺菌力ノ本態卜是レニ及ボス血液队諸成分，影響丹探究 セルキ以テ次ギ二膠質銀注射ノ際二於ケル尿成分，變化き兄. 夫レョリ體队新陳代謝 變化ノ狀況丹知ラントシテ本實驗二着手セリ。

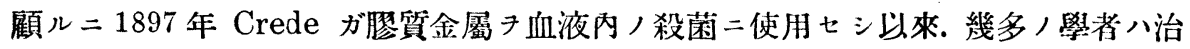
療上二膠質銀き應用スルニ至レリ。從ツテ膠質銀，新陳代謝二對スル影響も研究七ラ レタリ。

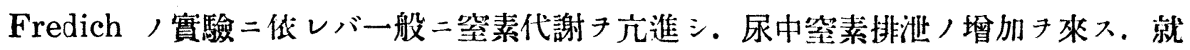
中尿酸排泄量ノ增加顯著ナル事キ報告セリ。

最近白川八. 金屬-Sol /静脈内注射站二皮下注射後二於テハ尿中二總究菜 Allantoin 及ビ尿酸ノ排泄量增加來入事證七リ。

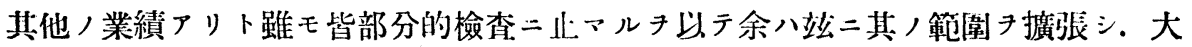

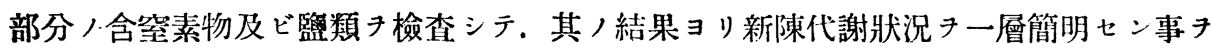
企圖セリ。

\section{第二章 實驗材料及ビ方法}

\section{第一項 研究材料}

實驗動物. 體重 2300 瓦以上 3000 瓦以下，雄家鬼丹使用ス。且ツ余／經驗上抵抗力 强キ黑色家鬼习撰ブ。

動物飼料: 豆腐涬卜生荣卜尹或一定/比二混和シタルモノ、一定量尹供ス。 


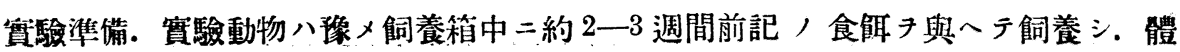
重,本均泣二窒素本衡み保ツニ至リテ實驗二使用セリ。

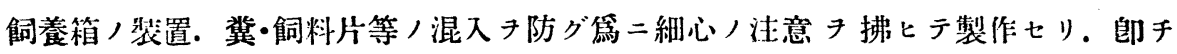

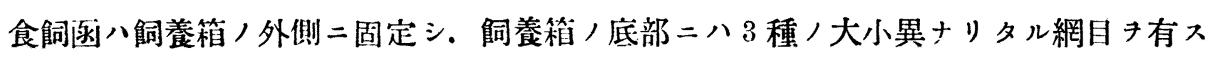

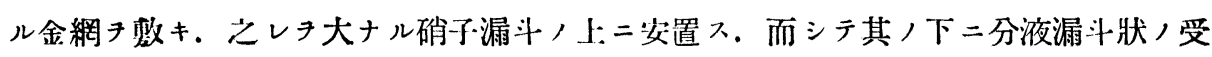
尿期丹裝置三全尿子貯集入。

受尿器二八像メToluol 3 c.c. 醋酸 10c.c. タ入レ. 次ギニ一定量！流動-Paraffin キ重

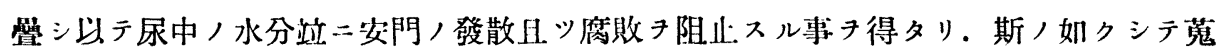
集シタル尿ハ常二酸性ニシテ且.ツ蔨濁キ見ザリキ。

飼養箱ハ必ズ 1 日 1 回金網上：污物 除去シ。食網. 漏斗. 受尿器ハ水洗シテ常ニ 清潔二保ツ。

\section{第二項 實驗方法}

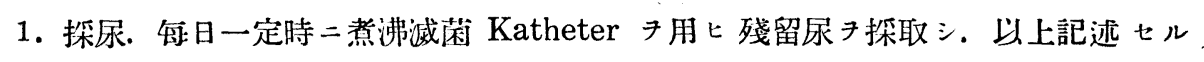
受尿器尿ト混和シ 24 時間ノ尿量ト入. 而シテ室溫ニ於テ尿量及ビ比重フ測定ス。

2. 體重. 採用直後二於テ計量入。

3. 尿/ 定性站二定量法

\section{A. 尿，定唑試驗法}

(1)蛋白檢查. Sulfosalizyl-酸試驗法

(2)糖檢查. Trommer 法及ビ Nylander 法キ用ヒタリ。

$$
\text { B. 尿，定量試驗法 }
$$

(1) 總䆙素. Kjeldahl 法

(2)安門突素. Van Slyke u. Cullen 法

(3)尿素空素. 同上: Urease 法

(4) Amino-酸栄素. Sörensen-Henriques. Formol-滴定法

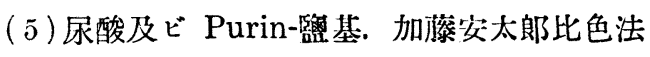

(6) Allantoin-穿素. Plimmer and Skelton 法

(7) Kreatinin-紫素. Folin 法

(8) 總燐酸. Uran 滴定法

(9) 總硫黃. Konschegg 法

(10)總硫酸及ビ Äther-硫酸. Salkowsky 法

(11) 中性硫黄. 總硫黄量ヨリ總硫酸, 硫黃量き引去りテ計算セリ, 


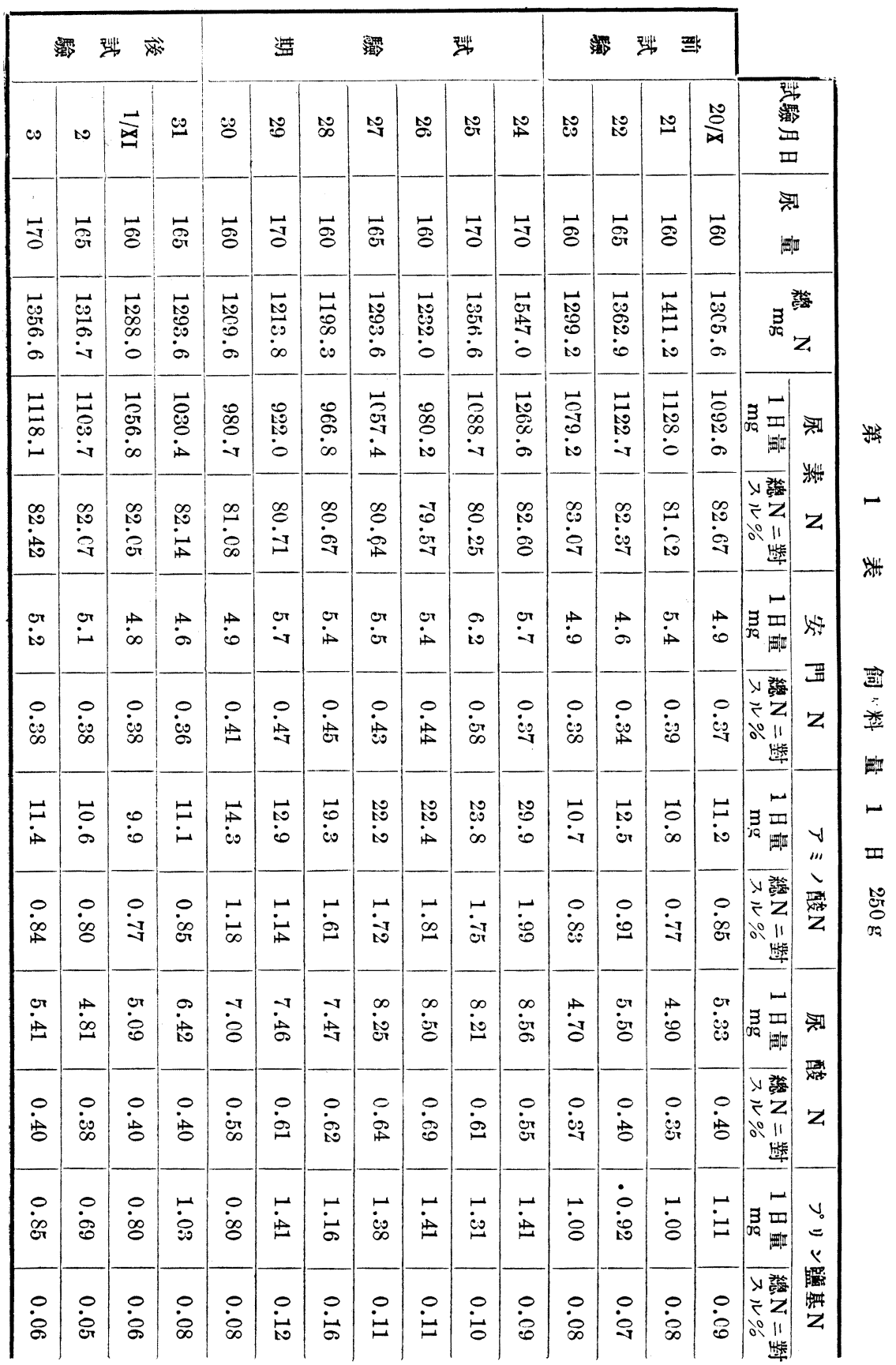




\begin{tabular}{|c|c|c|c|c|c|c|c|c|c|c|c|c|c|c|c|c|}
\hline $\begin{array}{c}8 \\
:-1\end{array}$ & $\begin{array}{l}\text { or } \\
\text { is }\end{array}$ & 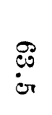 & $\begin{array}{l}\stackrel{8}{\circ} \\
0\end{array}$ & 苛 & $\begin{array}{l}\mathscr{8} \\
\dot{0}\end{array}$ & $\begin{array}{l}\sqrt{0} \\
: 0 \\
: 0\end{array}$ & $\begin{array}{l}\text { 惡 } \\
\text { is } \\
\text { is }\end{array}$ & 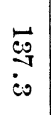 & $\begin{array}{l}\overrightarrow{0} \\
\dot{0}\end{array}$ & $\begin{array}{l}\vec{\circ} \\
\infty \\
\dot{\sigma}\end{array}$ & $\begin{array}{l}\text { o } \\
\infty \\
\text { io }\end{array}$ & $\stackrel{9}{10}$ & $\begin{array}{l}0 \\
0 \\
0 \\
0\end{array}$ & $\stackrel{\overrightarrow{0}}{0}$ & $\frac{-}{80}$ & $\begin{array}{l}y \\
y \\
v\end{array}$ \\
\hline $\begin{array}{l}\stackrel{0}{*} \\
\dot{\vec{L}}\end{array}$ & $\stackrel{\leftrightarrow}{\stackrel{c}{c}}$ & $\stackrel{P}{\infty}$ & $\underset{⿱ 丷}{r}$ & $\stackrel{\oplus}{\dot{P}}$ & $\vec{j}$ & $\begin{array}{l}\overrightarrow{0} \\
\text { iे }\end{array}$ & $\dot{\vec{\rho}}$ & $\underset{\vec{E}}{\vec{F}}$ & $\begin{array}{l}\infty \\
\dot{\infty} \\
\infty\end{array}$ & $\dot{0}_{10}$ & $\stackrel{\vec{i}}{\stackrel{\oplus}{\infty}}$ & $\stackrel{+}{8}$ & \begin{tabular}{l}
$\infty$ \\
$\vdots$ \\
\multirow{1}{*}{}
\end{tabular} & $\begin{array}{l}\text { or } \\
\dot{1}\end{array}$ & 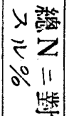 & $\vec{r}$ \\
\hline to & $\begin{array}{l}0 \\
\dot{0}\end{array}$ & $\begin{array}{l}\frac{1}{10} \\
\overrightarrow{0}\end{array}$ & $\begin{array}{l}\overrightarrow{0} \\
\dot{0}\end{array}$ & $\begin{array}{l}\stackrel{t}{0} \\
\text { or }\end{array}$ & $\stackrel{R}{\stackrel{R}{*}}$ & $\begin{array}{l}\stackrel{\overrightarrow{0}}{0} \\
\stackrel{0}{*}\end{array}$ & $\begin{array}{l}\stackrel{\vec{t}}{t 0} \\
\dot{c} 0\end{array}$ & $\begin{array}{l}\vec{t} \\
\stackrel{0}{0} \\
\dot{0}\end{array}$ & 苞 & $\begin{array}{l}\stackrel{\vec{c}}{\mathrm{in}} \\
\text { is }\end{array}$ & 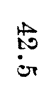 & $\begin{array}{l}\vec{b} \\
\dot{0}\end{array}$ & $\begin{array}{l}\mathbb{t} \\
\text { it }\end{array}$ & $\begin{array}{l}\frac{1}{15} \\
\dot{c}\end{array}$ & 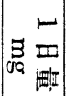 & $\begin{array}{l}v \\
y\end{array}$ \\
\hline $\begin{array}{l}\stackrel{0}{0} \\
\dot{\sigma}\end{array}$ & $\begin{array}{l}0 \\
\vdots \\
0 \\
0\end{array}$ & $\begin{array}{l}00 \\
\dot{\theta}\end{array}$ & $\begin{array}{l}0 \\
\vdots \\
\infty\end{array}$ & $\begin{array}{l}0 \\
\stackrel{0}{\sigma} \\
\dot{\sigma}\end{array}$ & $\begin{array}{l}\text { ب. } \\
\text { 台 }\end{array}$ & 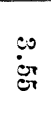 & 品 & 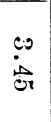 & $\begin{array}{l}\dot{0} \\
\dot{\vec{t}}\end{array}$ & $\begin{array}{l}10 \\
\ddot{8}\end{array}$ & $\begin{array}{l}\text { co } \\
\text { io }\end{array}$ & 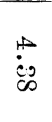 & $\stackrel{\varphi}{\dot{\rho}}$ & 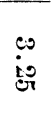 & 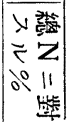 & $\mid \begin{array}{l}\mid+ \\
11 \\
x \\
z\end{array}$ \\
\hline $\begin{array}{l}\overrightarrow{\mathrm{E}} \\
\stackrel{5}{0} \\
\dot{6}\end{array}$ & $\begin{array}{l}\vec{T} \\
\text { or } \\
\vec{T}\end{array}$ & 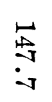 & 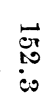 & $\begin{array}{l}\overrightarrow{1} \\
0 \\
0 \\
0\end{array}$ & $\begin{array}{l}\vec{B} \\
\dot{\infty} \\
\dot{\infty}\end{array}$ & $\begin{array}{l}\overrightarrow{0.0} \\
\dot{0}\end{array}$ & $\begin{array}{l}\sqrt{15} \\
\infty \\
0\end{array}$ & $\begin{array}{l}\overrightarrow{5} \\
\stackrel{5}{*}\end{array}$ & $\begin{array}{c}\overrightarrow{6} \cdot 0 \\
\infty \\
\infty\end{array}$ & $\underset{\sim}{\vec{F}}$ & $\begin{array}{l}\vec{B} \\
\infty\end{array}$ & 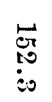 & $\begin{array}{l}\vec{A} \\
\stackrel{\vec{y}}{-7}\end{array}$ & $\begin{array}{l}\overrightarrow{0} \\
\dot{i}\end{array}$ & $B_{0 Q}^{3}$ & \\
\hline 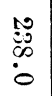 & 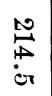 & $\begin{array}{l}\frac{10}{4} \\
0 \\
0 \\
0\end{array}$ & 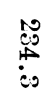 & $\begin{array}{l}10 \\
40 \\
50 \\
0 \\
0\end{array}$ & $\begin{array}{l}\frac{10}{\circ} \\
\stackrel{\circ}{\circ} \\
\dot{\sigma} r\end{array}$ & $\begin{array}{l}\stackrel{N}{0} \\
\stackrel{\leftrightarrow}{0} \\
\dot{0}\end{array}$ & $\begin{array}{l}\stackrel{5}{\circ} \\
\stackrel{+}{+} \\
0\end{array}$ & $\begin{array}{l}19 \\
\stackrel{10}{7} \\
\stackrel{0}{0}\end{array}$ & $\begin{array}{l}0 \\
0 \\
0 \\
\text { io }\end{array}$ & 量 & 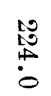 & $\begin{array}{l}\frac{10}{10} \\
\text { ơ } \\
0\end{array}$ & $\begin{array}{l}10 \\
c=0 \\
c=0 \\
0 \\
0\end{array}$ & $\begin{array}{l}10 \\
10 \\
10 \\
0 \\
0\end{array}$ & $\frac{B}{g}$ & 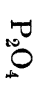 \\
\hline $\begin{array}{l}\vec{t} \\
0 \\
0 \\
\dot{0} \mathrm{r}\end{array}$ & $\begin{array}{l}\overrightarrow{0} \\
0 \\
0\end{array}$ & 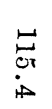 & $\overrightarrow{\vec{N}}$ & $\begin{array}{l}\stackrel{\vec{c}}{\stackrel{\oplus}{\perp}} \\
\stackrel{\bullet}{*}\end{array}$ & $\underset{c}{\stackrel{\overrightarrow{\mid}}{\overrightarrow{\mid}}}$ & $\begin{array}{l}\overrightarrow{5} \\
\text { is } \\
\text { io }\end{array}$ & $\begin{array}{l}\overrightarrow{c o} \\
\stackrel{0}{\circ} \\
\stackrel{0}{0}\end{array}$ & 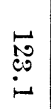 & $\begin{array}{c}\overrightarrow{c 0} \\
\stackrel{c}{c}\end{array}$ & $\begin{array}{l}\vec{c} \\
\stackrel{0}{0} \\
\vec{v}\end{array}$ & $\begin{array}{l}\overrightarrow{t o} \\
\stackrel{0}{0} \\
\dot{0}\end{array}$ & $\stackrel{\overrightarrow{10}}{\stackrel{\overrightarrow{10}}{\mathrm{r}}}$ & 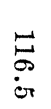 & $\begin{array}{l}\vec{a} \\
\stackrel{2}{6} \\
0\end{array}$ & $\underset{0 Q}{3}$ & \\
\hline $\begin{array}{l}\overrightarrow{8} \\
\overrightarrow{8} \\
\vec{v}\end{array}$ & $\begin{array}{l}\vec{\leftrightarrow} \\
\stackrel{4}{0} \\
\vec{v}\end{array}$ & $\begin{array}{l}\infty \\
\infty \\
\infty\end{array}$ & $\underset{\vec{\sigma}}{\overrightarrow{0}}$ & $\begin{array}{l}\overrightarrow{5} \\
\dot{0} \\
\dot{0}\end{array}$ & $\begin{array}{l}\vec{\sigma} \\
\dot{0}\end{array}$ & $\begin{array}{l}\overrightarrow{8} \\
\dot{8}\end{array}$ & $\underset{⿱ ㇒}{\rightleftarrows}$ & $\begin{array}{l}\vec{\rho} \\
\dot{\theta}\end{array}$ & 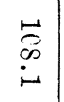 & $\underset{\dot{c}}{\overrightarrow{+}}$ & 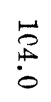 & 点 & $\begin{array}{l}8 \\
\dot{0}\end{array}$ & 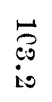 & 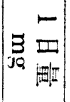 & 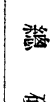 \\
\hline $\begin{array}{l}\infty \\
\stackrel{\infty}{\infty} \\
\text { is }\end{array}$ & $\begin{array}{l}\infty \\
\mathscr{0} \\
0\end{array}$ & $\begin{array}{l}\infty \\
0 \pi \\
0\end{array}$ & $\stackrel{\infty}{\stackrel{\infty}{0}}$ & $\stackrel{\infty}{\circ}$ & $\stackrel{\infty}{\infty}$ & $\begin{array}{l}\infty \\
\vdots 0 \\
0 \\
0\end{array}$ & $\stackrel{\infty}{\infty}$ & 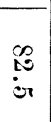 & $\begin{array}{l}\infty \\
5 \\
0\end{array}$ & $\stackrel{\infty}{\infty}$ & $\begin{array}{l}\infty \\
\stackrel{\infty}{0} \\
\dot{i o g}\end{array}$ & 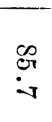 & $\begin{array}{l}\text { कo } \\
\text { io }\end{array}$ & $\begin{array}{l}\infty \\
\stackrel{\infty}{0} \\
0\end{array}$ & 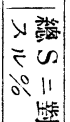 & 事 \\
\hline $\begin{array}{l}\vec{\infty} \\
\dot{\infty}\end{array}$ & $\begin{array}{l}\vec{\sigma} \\
\dot{0}\end{array}$ & $\begin{array}{l}\vec{\sigma} \\
\dot{0}\end{array}$ & $\begin{array}{l}\overrightarrow{0} \\
\dot{i}\end{array}$ & $\begin{array}{l}\stackrel{0}{0} \\
\dot{\sigma} \mathrm{r}\end{array}$ & 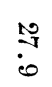 & $\stackrel{10}{\circ}$ & $\begin{array}{l}\hat{\bullet} \\
\dot{\sigma}\end{array}$ & $\begin{array}{l}\stackrel{n}{0} \\
\stackrel{0}{r}\end{array}$ & $\begin{array}{c}0 \\
0 \\
0 \\
v\end{array}$ & $\underset{i}{\stackrel{i}{i}}$ & $\vec{o}$ & $\vec{T}$ & $\overrightarrow{i_{0}}$ & $\begin{array}{l}\vec{\sigma} \\
\infty\end{array}$ & $\frac{1}{\pi}$ & Z \\
\hline$\underset{\infty}{\stackrel{5}{+}}$ & $\stackrel{\overrightarrow{\$}}{\stackrel{+}{\circ}}$ & $\underset{i}{\stackrel{\vec{D}}{+}}$ & $\begin{array}{l}\overline{c r} \\
\dot{\sigma}\end{array}$ & $\vec{\bullet}$ & $\begin{array}{l}\overrightarrow{0} \\
\dot{\theta}\end{array}$ & $\underset{-\vec{v}}{\vec{v}}$ & $\begin{array}{l}\vec{\infty} \\
\dot{\phi}\end{array}$ & $\begin{array}{l}\vec{T} \\
\dot{v}\end{array}$ & $\begin{array}{l}\overrightarrow{0} \\
0\end{array}$ & $\begin{array}{l}\vec{\infty} \\
\dot{\infty}\end{array}$ & $\begin{array}{r}\vec{c} \cdot 0 \\
\vec{v}\end{array}$ & $\underset{C_{0}}{\vec{P}}$ & $\underset{\infty}{\stackrel{+}{+}}$ & $\stackrel{\vec{F}}{\dot{0}}$ & 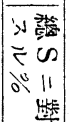 & 密 \\
\hline$\stackrel{P}{i}$ & $\begin{array}{l}0 \\
0\end{array}$ & $\stackrel{\oplus}{i}$ & $\underset{\infty}{\infty}$ & $\underset{r}{\stackrel{r}{r}}$ & $\underset{i 0}{\phi}$ & $\dot{0}$ & $\begin{array}{l}\dot{\theta} \\
\dot{c}\end{array}$ & $\vec{i}$ & $\dot{\theta}$ & $\stackrel{p}{i o}$ & $\underset{\infty}{\stackrel{r}{0}}$ & $\stackrel{\stackrel{\sigma}{r}}{\sim}$ & $\stackrel{v}{i}$ & $\stackrel{P}{i}$ & 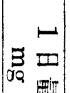 & $\stackrel{H}{i}$ \\
\hline $\begin{array}{l}0 \\
\ddot{0}\end{array}$ & $\stackrel{\overrightarrow{0}}{0}$ & $\begin{array}{l}\vec{r} \\
\dot{r}\end{array}$ & rr & $\stackrel{+}{\dot{c}}$ & $\stackrel{\circ}{0}$ & $\stackrel{4}{0}$ & $\underset{i v}{c r}$ & $\begin{array}{l}0 r \\
0\end{array}$ & $\underset{\infty}{+}$ & $\stackrel{\vec{i}}{\vec{b}}$ & $\underset{\infty}{\dot{\infty}}$ & $\stackrel{+}{\circ}$ & $\underset{r}{\stackrel{r}{r}}$ & ث̈ & 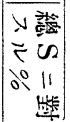 & 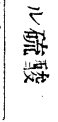 \\
\hline \multirow[t]{2}{*}{$\begin{array}{l}0 \\
\stackrel{0}{0.0} \\
8\end{array}$} & $\begin{array}{l}10 \\
100 \\
0 \\
0\end{array}$ & $\begin{array}{l}0 \\
\ddot{0} \\
\ddot{0}\end{array}$ & 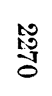 & 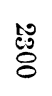 & $\begin{array}{l}1: 0 \\
15 \\
0 \\
0\end{array}$ & $\begin{array}{l}1: 2 \\
15 \\
8 \\
8\end{array}$ & $\begin{array}{l}\stackrel{10}{0} \\
\stackrel{0}{8}\end{array}$ & $\begin{array}{l}\mathbb{1} \\
\stackrel{\mathbb{N}}{0} \\
0\end{array}$ & $\begin{array}{l}10 \\
15 \\
00 \\
0\end{array}$ & $\begin{array}{l}10 \\
: 02 \\
8\end{array}$ & 占 & $\begin{array}{l}10 \\
\stackrel{10}{0} \\
8\end{array}$ & $\begin{array}{l}10 \\
10 \\
0 \\
0\end{array}$ & 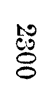 & & \\
\hline & & & & 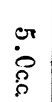 & 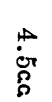 & $\begin{array}{l}+ \\
\stackrel{\leftrightarrow}{0} \\
\stackrel{0}{0}\end{array}$ & $\begin{array}{l}0 \\
\dot{\theta} \\
\stackrel{R}{\Omega}\end{array}$ & $\begin{array}{l}0 \\
\dot{0} \\
\dot{\rho} \\
ٍ\end{array}$ & $\begin{array}{l}0 \\
\dot{0} \\
\tilde{D} \\
\Omega\end{array}$ & $\begin{array}{l}\circ \\
\dot{8} \\
\stackrel{\rho}{8}\end{array}$ & & & & & & 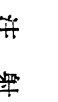 \\
\hline
\end{tabular}




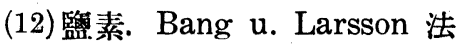

4. 注射方法

膠質銀 7 每:日一定時二 1 回宛靜脈内二注射シ 1 週間繼續ス. 初メョリ大量 7 注射ス

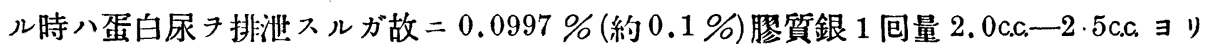

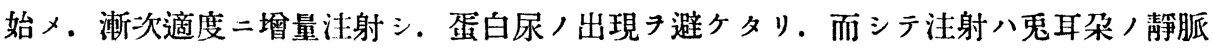
ニ行フ。

\section{第三章 實驗成績}

\section{第 1 實驗 (第 1 表)}

健雉家鬼(體重 2300 瓦) キ当素本衡狀態二保持セシメタルモノチ４日間二瓦リ前

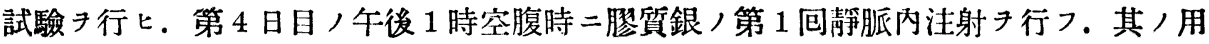
量八最初 2.0 c.c. ト シ. 第 2 回ヨリ八漱次 0.5 c.c. 宛增量スル時八蛋白尿タ起サズシテ第 7 问注射量 5.0 c.c. ニ達スル事タ得タリ。

臨牀上所見

注射後食慈佳良. 體重, 增減二著變ナシ。體溫八第 1 包注射後二於テ輕度,上昇ヨ 認ム卜雖モ。一般二其後/注射二於テハ是习認メズ。而シテ其ノ體溫上年ノ程度モ $1^{\supset} \mathrm{C}$ モ内外二止マル。

尿所見

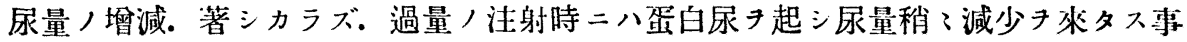
アレドモ。余ノ實驗ニ於テハ斯ノ如キ場合キ避ケタルキ以テ尿量/減少ハ著シカラズ。 蛋白及糖檢査. 共二總テ陰性ナリ。

尿總聜素量. 第 1 包注射後稍 3 增加スルモ. 第 2 包以後八前試驗尿總營素量ヨリモ 稍々減少ノ倾问丹示ス。

尿素突素量. 第 1 回注射後絶對量八增加スレドモ 100 分率八艄 、減少セリ。第 2 回 注射以後八䋓對量站二 100 分率共二漱次低下七り。

安門䆓素量. 鬼尿ハ常二其量僅少ニシラ゙注射後モ極少量ノ增加チ示スニ過ギズ。

Amino-酸空素量. 第 1 回㳡射後常尿ノ場合ノ約 2 倍二增量三.漱次低下シテ第 7 回 注射後ハ $40 \%$, 增加丹示ス. 注射中止後ハ常尿, 其レニ接近シ.後試驗第 3 日目二至 レバ前試驗ヨリ低下ス，更二再ビ復歸ス。

尿酸空素量. 第 1 回注射二依り $60 \%$ /增加 キ示ス. 第 2 间以後僅力二減少シテ第 7 回注射後ハ $55 \%$ ，增量トナル。注射中止後直チ二復歸入。 
Purin-監基窒素量. 極メテ微量ナルモ僅カ二增加／傾向キ示ス。

Allantoin-窒素量. 第 1 回注射後約 $80 \%$ 增量シ. 濑次增量第 4 回注射後其/最大增 加量 $123 \%$ 二達シ其レ以後漱次低下シ. 第 7 包洼射後 $19 \%$ ，增加二過ギズ. 注射中止 後八直于二減少シテ本常量二復歸セリ。

Kreatinin-辪素量. 注射二依ル影響タ認メズ,

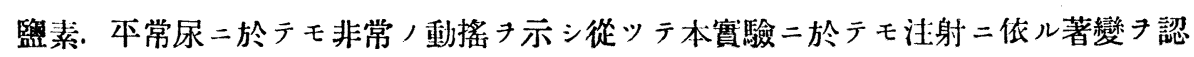
ムル事能ハズト雖モ稍了減少ノ傾问アリ。

總燐酸. 注射二依り多少增加八倾アリ。( $9 \%)$

總硫溭。，排泄八注射ニョリ著シク增加シ. 就中. 中性硫黃ノ增加著シク (約 $44 \%)$. 總硫酸八注射後絕對量八稍 3 增如スルモ 100 分率八却ッテ減少シ. Äther-硫酸八絕對 量泣二 100 分率ニ於テモ變化ナシ，

第 2 實驗 (第 2 表)

體重 2890 瓦，健雄家鬼子第 1 實驗卜同樣，條件，下二實驗子施行ス。但三前後諾驗

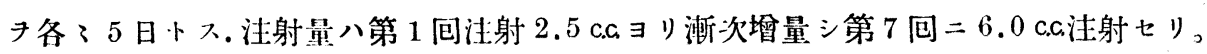

臨牀的所見

注射後モ食慈可良ニシテ體重, 增減八著變ナシ。體溫ノ上开著明ナラズ。

尿所胃

尿量! 增娍。異常ナシ。

蛋白・糖检査. 共二總テ陰性ナリ。

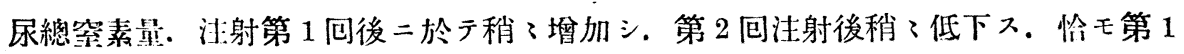
表ト殆ンド同成縝キ示ス。

尿素突素量. 第 1 實驗卜同成績ナリ。

安門營素量. 注射後增娍ナシ。

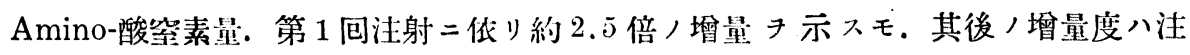
射尹重于ルモ却ツテ渐低三第 7 回注射後ハ約 $17 \%$ 增量二過ギズ, 注射中止後八正 常量二復入。

尿酸䇪素量. 第 1 回注射ニヨリ $64 \%$ 增加三漱次低下入。

Purin-監基空素量. 稍 3 增加 ス。

Allantoin-空素量. 第 1 回注射後約 $70 \%$ ，增加 示シ.增量注射卜共二漱次增加シ第 4 回注射二於テ最大增加量二達シ.後軲減七り。注射中止後直チ二減シテ本常量二復入。 Kreatinin-空素量. 注射二依儿變化認メズ。 


\begin{tabular}{|c|c|c|c|c|c|c|c|c|c|c|c|c|c|c|c|c|c|c|}
\hline \multicolumn{2}{|c|}{ 经 } & 㻦 & \multicolumn{2}{|c|}{ 球 } & \multicolumn{3}{|c|}{ 䖪 } & \multicolumn{2}{|l|}{ 䍝 } & \multicolumn{2}{|l|}{ 䢃 } & \multicolumn{2}{|c|}{ 虂 } & \multicolumn{3}{|l|}{ 玻 } & \multirow{2}{*}{\multicolumn{2}{|c|}{ 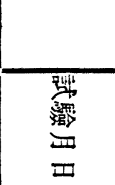 }} \\
\hline 15 & 10 & $\stackrel{10}{\theta}$ & $\stackrel{0}{\circ}$ & $\vec{\omega}$ & $\vec{\infty}$ & $\vec{v}$ & $\vec{\sigma}$ & $\overrightarrow{\mathrm{c}}$ & $\vec{A}$ & $\overrightarrow{00}$ & $\vec{v}$ & • & ప & 0 & $\infty$ & $\stackrel{\overrightarrow{⿱ 亠 凶}}{\vec{\theta}}$ & & \\
\hline $\overrightarrow{\&}$ & $\vec{b}$ & $\overrightarrow{\tilde{\sigma}}$ & $\vec{\circ}$ & $\vec{~}$ & $\overrightarrow{8}$ & $\overrightarrow{8}$ & $\overrightarrow{8}$ & $\vec{O}$ & $\overrightarrow{8}$ & $\vec{g}$ & $\overrightarrow{\mathscr{g}}$ & $\overrightarrow{8}$ & $\vec{\Theta}$ & $\overrightarrow{8}$ & $\overrightarrow{0}$ & $\overrightarrow{8}$ & & 灌 \\
\hline 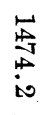 & 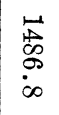 & 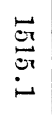 & $\begin{array}{l}\stackrel{\vec{s}}{\stackrel{\leftrightarrow}{0}} \\
\dot{0}\end{array}$ & $\begin{array}{l}\text { 点 } \\
\text { 密 } \\
\text { is }\end{array}$ & $\begin{array}{l}\vec{c} \\
.0 \\
\stackrel{\circ}{0} \\
\dot{0}\end{array}$ & $\begin{array}{l}\overrightarrow{P .0} \\
\overrightarrow{0.9} \\
\stackrel{9}{0} \\
\dot{0}\end{array}$ & $\begin{array}{l}\overrightarrow{c: 0} \\
\stackrel{0}{0} \\
\stackrel{0}{0} \\
\dot{0}\end{array}$ & $\begin{array}{l}\stackrel{\vec{c}}{0} \\
\stackrel{0}{0}\end{array}$ & $\underset{ت}{\stackrel{E}{*}}$ & $\begin{array}{l}\text { 鹤 } \\
\text { i } \\
\text { i }\end{array}$ & $\begin{array}{l}\overrightarrow{0} \\
\overrightarrow{0} \\
+\infty\end{array}$ & $\begin{array}{l}\stackrel{\vec{A}}{\vec{A}} \\
\stackrel{+}{0}\end{array}$ & 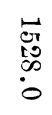 & $\begin{array}{l}\vec{c} \\
\stackrel{c}{1} \\
i \\
i s\end{array}$ & $\begin{array}{l}\overrightarrow{8} \\
\stackrel{8}{0} \\
\stackrel{0}{0}\end{array}$ & 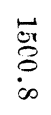 & $\mathbb{S}_{\infty}^{Z}$ & \\
\hline $\begin{array}{l}\overrightarrow{5} \\
\stackrel{0}{\infty} \\
\stackrel{\leftrightarrow}{\infty} \\
\infty\end{array}$ & 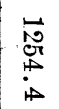 & $\begin{array}{l}\sqrt{50} \\
-T \\
0 \\
0 \\
0\end{array}$ & $\begin{array}{l}\overrightarrow{10} \\
\mathbb{5} \\
\text { : } \\
\text { is }\end{array}$ & $\begin{array}{l}\text { 点 } \\
6 \\
0 \\
0\end{array}$ & 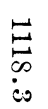 & $\begin{array}{l}\vec{D} \\
\vec{D} \\
\dot{0} \\
\dot{i}\end{array}$ & 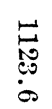 & $\begin{array}{l}\vec{c} \\
\stackrel{\overrightarrow{0}}{\circ} \\
\dot{\sigma}\end{array}$ & $\begin{array}{c}\vec{F} \\
\stackrel{0}{0} \\
\dot{0} \\
0\end{array}$ & $\begin{array}{l}\vec{F} \\
\infty \\
\infty \\
\infty\end{array}$ & 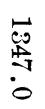 & $\begin{array}{l}\overrightarrow{10} \\
15 \\
10 \\
\text { is }\end{array}$ & $\begin{array}{l}\overrightarrow{10} \\
60 \\
0 \\
-0\end{array}$ & $\begin{array}{l}\text { t.9 } \\
\text { 点 } \\
0 \\
0\end{array}$ & $\begin{array}{l}\overrightarrow{1} \\
07 \\
0 \\
0 \\
0\end{array}$ & $\begin{array}{l}\vec{w} \\
\stackrel{5}{0} \\
0 \\
0\end{array}$ & 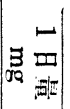 & $\begin{array}{l}\text { 필 } \\
\text { 粈 }\end{array}$ \\
\hline 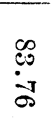 & 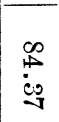 & $\begin{array}{c}\stackrel{\infty}{\infty} \\
\stackrel{\infty}{\infty}\end{array}$ & 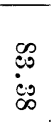 & $\begin{array}{l}\infty \\
0 \\
0 \\
8\end{array}$ & $\begin{array}{l}\infty \\
\dot{0} \\
\dot{\infty}\end{array}$ & $\stackrel{\infty}{\stackrel{\infty}{\infty}}$ & $\stackrel{\infty}{\stackrel{\circ}{\circ}}$ & $\stackrel{\infty}{\stackrel{\infty}{\infty}}$ & $\stackrel{\infty}{\stackrel{\infty}{\leftrightarrow}}$ & 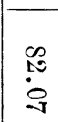 & \begin{tabular}{l}
$\infty$ \\
$: 0$ \\
$: 3$ \\
\hdashline
\end{tabular} & $\begin{array}{l}\infty \\
c \\
\dot{c} \\
\dot{c} \\
\infty\end{array}$ & 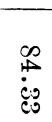 & 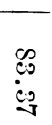 & $\begin{array}{l}\infty \\
\dot{c} \\
9 \\
9\end{array}$ & 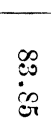 & 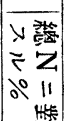 & $\begin{array}{l}\text { 时 } \\
\text { 粈 }\end{array}$ \\
\hline$\stackrel{0}{0}$ & $\begin{array}{l}\dot{c} \\
\dot{\sigma}\end{array}$ & $\begin{array}{l}\text { or } \\
\text { io }\end{array}$ & $\begin{array}{l}\text { or } \\
\text { ris }\end{array}$ & $\begin{array}{l}\text { or } \\
\text { is }\end{array}$ & $\begin{array}{l}\text { er } \\
\text { rot }\end{array}$ & ir & $\stackrel{d r}{r}$ & $\stackrel{\sigma r}{\sigma}$ & $\begin{array}{l}\text { or } \\
\text { or }\end{array}$ & rr & $\stackrel{\oplus}{\dot{1}}$ & $\begin{array}{l}\text { or } \\
\text { or }\end{array}$ & $i_{\text {is }}$ & or & $\stackrel{\rho}{i}$ & $\underset{i}{o r}$ & $\underset{B R}{5}$ & 婃 \\
\hline $\begin{array}{l}0 \\
i, 0 \\
i\end{array}$ & $\stackrel{0}{i g}$ & $\begin{array}{l}0 \\
\dot{\dot{c}} \\
\dot{c} 0\end{array}$ & $\stackrel{0}{i \infty}$ & $\begin{array}{l}0 \\
\dot{\phi}\end{array}$ & $\begin{array}{l}\dot{0} \\
\dot{\theta}\end{array}$ & $\begin{array}{l}0 \\
\dot{e}\end{array}$ & 造 & $\stackrel{0}{\dot{\theta}}$ & ஜ & 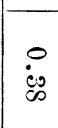 & $\begin{array}{l}0 \\
\dot{c o s} \\
\dot{v}\end{array}$ & $\begin{array}{l}0 \\
\dot{0} \\
\dot{\infty}\end{array}$ & $\stackrel{\dot{D}}{\dot{\Delta}}$ & $\begin{array}{l}0 \\
\dot{i=}\end{array}$ & 官 & 郘 & 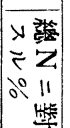 & $\begin{array}{l}\text { I } \\
z\end{array}$ \\
\hline $\begin{array}{l}\vec{c} \cdot 0 \\
\dot{0}\end{array}$ & 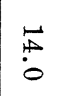 & $\begin{array}{l}10 \\
0 \\
0\end{array}$ & $\begin{array}{l}\overrightarrow{0} \\
\dot{0} \\
0\end{array}$ & $\underset{\dot{c}}{\stackrel{\vec{P}}{r}}$ & $\dot{\circ}$ & $\begin{array}{l}\vec{T} \\
\text { or }\end{array}$ & $\begin{array}{l}10 \\
: 0 \\
: 10\end{array}$ & $\stackrel{+0}{\stackrel{1}{+}}$ & 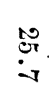 & $\begin{array}{l}\text { cog } \\
\text { cot }\end{array}$ & $\stackrel{\infty}{+\infty}$ & $\begin{array}{l}\overrightarrow{10} \\
\dot{0}\end{array}$ & $\begin{array}{l}10 \\
00\end{array}$ & $\begin{array}{l}\overrightarrow{0} \\
\infty \\
\infty\end{array}$ & $\begin{array}{l}\vec{c} \\
\dot{0}\end{array}$ & $\begin{array}{l}\overrightarrow{0} \\
\dot{0}\end{array}$ & 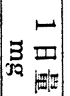 & $\begin{array}{l}y \\
\prime \prime \prime\end{array}$ \\
\hline $\begin{array}{l}0 \\
0 \\
i 0\end{array}$ & $\dot{\Leftrightarrow}$ & $\begin{array}{l}0 \\
\dot{c} \\
\stackrel{\leftrightarrow}{\sigma})\end{array}$ & $\dot{\infty}$ & $\dot{\circ}$ & $\dot{\omega}$ & 䓹 & $\stackrel{\bullet}{\oplus}$ & $\stackrel{ా}{\dot{\infty}}$ & $\stackrel{-1}{0}$ & مै & $\stackrel{\circ}{\circ}$ & $\dot{0}$ & $\stackrel{\infty}{\infty}_{\infty}$ & $\dot{\phi}_{i s}$ & $\stackrel{0}{0}$ & $\begin{array}{l}0 \\
\dot{c} \\
\dot{C}\end{array}$ & 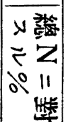 & ב \\
\hline$\stackrel{+}{i s}$ & $\begin{array}{l}\text { or } \\
\text { do }\end{array}$ & $\vec{c}$ & $\stackrel{+}{i 0}$ & $\stackrel{0}{0}$ & $\dot{0}$ & $\dot{d o}_{\text {co }}$ & $\therefore$ & $\stackrel{0}{\dot{c}}$ & $\dot{\phi}$ & $\ddot{0}_{0}^{-1}$ & $\dot{0}$ & $\stackrel{\leftrightarrow}{\dot{c}}$ & $\stackrel{0}{0}^{\circ}$ & $\begin{array}{l}0 r \\
\dot{c o s}\end{array}$ & $\underset{c o}{+}$ & $\stackrel{+}{0}$ & 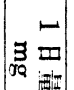 & 经 \\
\hline is & : & $\stackrel{0}{i}_{i}$ & i: & $\stackrel{\circ}{\dot{c}}$ & $\stackrel{0}{i}$ & $\stackrel{0}{\dot{\phi}}$ & $\begin{array}{l}0 \\
\text { 它 }\end{array}$ & 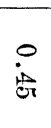 & $\begin{array}{l}0 \\
\text { is }\end{array}$ & 通 & $\stackrel{\circ}{\stackrel{0}{C}}$ & is & $\dot{i}_{i, j}$ & 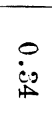 & $\begin{array}{l}0 \\
\text { is }\end{array}$ & is & 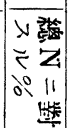 & $\begin{array}{l}z \\
z\end{array}$ \\
\hline $\begin{array}{l}\text { 品 } \\
\text { 客 }\end{array}$ & $\stackrel{\circ}{\dot{\theta}}$ & $\begin{array}{l}\circ \\
\dot{\phi} \\
\dot{\infty}\end{array}$ & $\dot{8}$ & $\dot{\circ}$ & $\dot{8}$ & $\dot{\dot{8}}$ & $\ddot{\rightleftarrows}$ & 官 & i。 & is & 客 & ig & $\dot{\mathscr{B}}$ & $\stackrel{\circ}{\stackrel{\circ}{\Delta}}$ & $\begin{array}{l}0 \\
\dot{\dot{\theta}}\end{array}$ & $\dot{\circ}$ & $\frac{1}{3}$ & $\begin{array}{l}U_{0} \\
=\end{array}$ \\
\hline$\dot{0}$ & $\dot{\circ}$ & $\dot{\circ}$ & $\dot{\vec{B}}$ & $\dot{\vec{c}}$ & $\dot{0}$ & $\dot{0}$ & $\dot{\dot{\infty}}$ & $\dot{8}$ & $\dot{0}$ & $\dot{\Xi}$ & $\begin{array}{l}\circ \\
\dot{8}\end{array}$ & $\dot{\ddot{C}}$ & $\dot{\circ}$ & $\stackrel{\circ}{\dot{1}}$ & $\stackrel{\circ}{\dot{\omega}}$ & $\dot{0}$ & 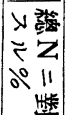 & 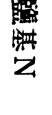 \\
\hline
\end{tabular}




\begin{tabular}{|c|c|c|c|c|c|c|c|c|c|c|c|c|c|c|c|c|c|c|}
\hline $\begin{array}{l}\int_{0} \\
\text { in }\end{array}$ & $\stackrel{0}{\dot{0}}$ & $\begin{array}{l}\text { J } \\
\text { is }\end{array}$ & $\stackrel{\rho}{0}$ & $\begin{array}{l}\text { Co } \\
\text { iे }\end{array}$ & $\begin{array}{l}\overrightarrow{0} \\
\varnothing \\
0\end{array}$ & 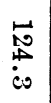 & $\begin{array}{l}\vec{A} \\
\text { 它 } \\
\dot{i}\end{array}$ & 贵 & $\begin{array}{c}\vec{\omega} \\
\dot{c} \\
i\end{array}$ & $\begin{array}{c}\overrightarrow{\vec{c}} \\
\dot{0}\end{array}$ & $\begin{array}{l}\vec{b} \\
\dot{B} \\
\dot{1}\end{array}$ & $\stackrel{\rho}{\stackrel{0}{0}}$ & $\begin{array}{l}\stackrel{8}{3} \\
\dot{\omega} \sigma\end{array}$ & $\stackrel{0}{\stackrel{0}{0}}$ & $\begin{array}{l}\stackrel{B}{1} \\
\dot{c}\end{array}$ & $\vec{i}$ & 思要 & $\begin{array}{l}y \\
v \\
v \\
v\end{array}$ \\
\hline $\begin{array}{l}\dot{0} \\
\dot{0}\end{array}$ & $\stackrel{\mapsto}{\bullet}$ & 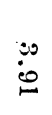 & $\stackrel{\vec{i}}{\vec{i}}$ & $\stackrel{\vec{b}}{\dot{b}}$ & $\begin{array}{l}0 \\
\dot{\infty}\end{array}$ & $\begin{array}{l}0 \\
\dot{\phi} \\
\dot{\phi}\end{array}$ & $\begin{array}{l}\overrightarrow{0} \\
\dot{i} \\
i=0\end{array}$ & $\begin{array}{l}\overrightarrow{0} \\
\dot{\theta} \\
\sigma\end{array}$ & $\dot{\infty}$ & $\dot{\infty}$ & $\begin{array}{l}\dot{0} \\
\dot{g}\end{array}$ & $\overrightarrow{\dot{8}}$ & 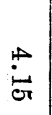 & $\begin{array}{l}0 \\
\dot{0} \\
\dot{0}\end{array}$ & $\stackrel{\vec{c}}{\vec{c}}$ & $\stackrel{+}{8}$ & 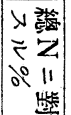 & $\vec{y}$ \\
\hline $\begin{array}{l}\vec{A} \\
0\end{array}$ & $\begin{array}{l}\text { 出 } \\
0\end{array}$ & $\stackrel{\overrightarrow{0}}{\stackrel{0}{-}}$ & $\begin{array}{l}\vec{A} \\
\dot{0}\end{array}$ & $\stackrel{b}{e}$ & $\begin{array}{l}\text { 孛 } \\
0\end{array}$ & $\begin{array}{l}t^{4} \\
0\end{array}$ & $\begin{array}{l}\text { 出 } \\
0\end{array}$ & $\begin{array}{l}c \\
c .0 \\
\dot{c} \sigma\end{array}$ & $\begin{array}{l}\overrightarrow{1} \\
0\end{array}$ & $\begin{array}{l}A \\
0 \\
0\end{array}$ & $\begin{array}{l}A \\
0 \\
0\end{array}$ & $\begin{array}{l}\overrightarrow{1} \\
0\end{array}$ & $\begin{array}{l}\overrightarrow{0} \\
\dot{0}\end{array}$ & $\begin{array}{l}\vec{t} \\
0\end{array}$ & $\begin{array}{c}\vec{v} \\
0\end{array}$ & $\stackrel{\vec{c}}{\vec{v}}$ & 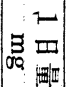 & $\vec{r}$ \\
\hline 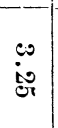 & $\begin{array}{l}\omega_{0} \\
\text { i⿱ } \\
\text { in }\end{array}$ & $\begin{array}{l}0 \\
i, 0 \\
i \neq\end{array}$ & $\begin{array}{l}00 \\
i o . \\
i \infty\end{array}$ & $\begin{array}{l}0 \\
\stackrel{\oplus}{\oplus}\end{array}$ & $\begin{array}{l}0 \\
\dot{\theta} \\
\Delta\end{array}$ & $\begin{array}{l}0 \\
\dot{c} \\
\dot{c} \\
\dot{c}\end{array}$ & $\begin{array}{l}\dot{c} \\
\dot{\Delta}\end{array}$ & $\begin{array}{l}0 \\
\dot{0}\end{array}$ & $\begin{array}{c}0 \\
\dot{c} \\
0 \\
0\end{array}$ & $\begin{array}{l}0 \\
0 \\
0 \\
0.0 \\
0.0\end{array}$ & $\begin{array}{l}0 \\
\dot{0} \\
\dot{j}\end{array}$ & 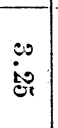 & $\begin{array}{l}\dot{0} \\
\dot{i v} \\
\dot{\omega}\end{array}$ & $\begin{array}{l}\omega \\
\dot{\rho}\end{array}$ & $\begin{array}{l}0 \\
\dot{\Xi} \\
0\end{array}$ & $\begin{array}{c}0 \\
\dot{\phi}\end{array}$ & 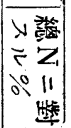 & $\begin{array}{l}+1 \\
11 \\
c \\
z\end{array}$ \\
\hline $\begin{array}{l}\vec{\circ} \\
\stackrel{\circ}{\circ} \\
\dot{\sim}\end{array}$ & $\begin{array}{l}\vec{c} \\
\stackrel{c}{0} \\
\dot{0}\end{array}$ & $\vec{O}$ & $\begin{array}{l}\overrightarrow{\mathrm{d}} \\
\stackrel{0}{\mathrm{i}}\end{array}$ & 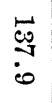 & $\stackrel{\overrightarrow{0}}{\stackrel{\overrightarrow{0}}{i}}$ & $\stackrel{\vec{E}}{\stackrel{\overrightarrow{0}}{i}}$ & $\begin{array}{c}\vec{b} \\
\stackrel{a}{0} \\
0\end{array}$ & $\begin{array}{l}\overrightarrow{8} \\
\dot{0}\end{array}$ & $\begin{array}{l}\vec{v} \\
\vec{v} \\
\infty\end{array}$ & $\begin{array}{l}\overrightarrow{0} \\
\infty \\
0\end{array}$ & $\begin{array}{l}\overrightarrow{\vec{v}} \\
\overrightarrow{7} \\
\vec{c}\end{array}$ & 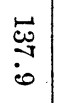 & 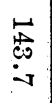 & $\begin{array}{l}\vec{c} \\
\stackrel{4}{\infty} \\
\dot{i}\end{array}$ & $\begin{array}{l}\vec{c} \\
\dot{c} \\
\dot{c} \\
\dot{c}\end{array}$ & $\begin{array}{l}\text { 惡 } \\
\dot{0}\end{array}$ & 焉 & 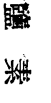 \\
\hline $\begin{array}{l}\mathbb{1} \\
\text { Ò } \\
0\end{array}$ & $\begin{array}{l}\stackrel{N}{\circ} \\
\stackrel{\leftrightarrow}{0}\end{array}$ & $\begin{array}{l}\text { D. } \\
\infty \\
\text { or }\end{array}$ & $\begin{array}{l}\infty \\
\infty \\
\infty \\
0\end{array}$ & $\begin{array}{l}\text { vo } \\
\text { ir }\end{array}$ & $\begin{array}{l}10 \\
\infty \\
\infty \\
0 \\
0\end{array}$ & 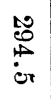 & $\begin{array}{l}\mathscr{0} \\
\stackrel{0}{0} \\
\dot{0}\end{array}$ & $\begin{array}{l}1 \\
o \\
o \\
\dot{o r}\end{array}$ & $\begin{array}{l}10 \\
-0 \\
0 \\
0\end{array}$ & 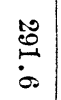 & 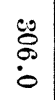 & $\begin{array}{l}10 \\
\infty \\
i \\
\text { is }\end{array}$ & 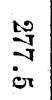 & \begin{tabular}{c}
$\stackrel{0}{0}$ \\
\hdashline \\
0
\end{tabular} & $\begin{array}{l}\text { :T } \\
0 \\
0 \\
0\end{array}$ & 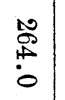 & $\underset{\sigma Q}{s}$ & 篦 \\
\hline $\begin{array}{l}\stackrel{\vec{*}}{*} \\
0\end{array}$ & 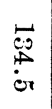 & $\begin{array}{l}\overrightarrow{c o} \\
\stackrel{0}{\infty} \\
\dot{\infty}\end{array}$ & 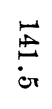 & $\begin{array}{l}\infty \\
\infty \\
\infty \\
\infty\end{array}$ & $\begin{array}{l}\overrightarrow{5} \\
\stackrel{5}{0} \\
\stackrel{2}{*}\end{array}$ & $\begin{array}{l}\vec{E} \\
\dot{0}\end{array}$ & $\begin{array}{l}\overrightarrow{\mathscr{E}_{0}} \\
\dot{0}\end{array}$ & 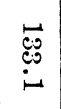 & $\begin{array}{l}\vec{c} \\
\stackrel{90}{10} \\
i t\end{array}$ & 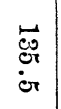 & $\begin{array}{l}\vec{c} \\
\stackrel{5}{0} \\
0\end{array}$ & 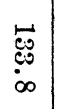 & $\begin{array}{l}\text { 点 } \\
\stackrel{i}{i}\end{array}$ & $\begin{array}{l}\overrightarrow{5} \\
0 \\
6\end{array}$ & $\begin{array}{l}\vec{E} \\
\text { is }\end{array}$ & $\begin{array}{l}\text { 崖 } \\
\dot{c}\end{array}$ & $\underset{8}{z}$ & \\
\hline $\begin{array}{c}\overrightarrow{10} \\
\stackrel{5}{0} \\
0\end{array}$ & $\underset{\infty}{\vec{\infty}}$ & $\begin{array}{l}\overrightarrow{8} \\
\text { io }\end{array}$ & $\stackrel{\overrightarrow{0}}{\stackrel{\overrightarrow{0}}{i 0}}$ & $\underset{⿱ 丷}{\vec{\sigma}}$ & $\begin{array}{l}\overrightarrow{8} \\
\infty \\
\dot{i}\end{array}$ & $\begin{array}{l}\vec{W} \\
\infty \\
\infty\end{array}$ & $\begin{array}{l}\overrightarrow{\mid} \\
: 0 \\
0\end{array}$ & $\begin{array}{l}\vec{a} \\
\text { io }\end{array}$ & $\begin{array}{l}\overrightarrow{0} \\
\dot{0} \\
\dot{\sigma}\end{array}$ & $\begin{array}{l}\overrightarrow{5} \\
+0 \\
\infty\end{array}$ & $\begin{array}{l}\overrightarrow{0} \\
\stackrel{0}{0} \\
\dot{\infty}\end{array}$ & $\begin{array}{l}\overrightarrow{\vec{\sigma}} \\
\ddot{v}\end{array}$ & $\begin{array}{l}\stackrel{\overrightarrow{5}}{10} \\
\stackrel{+}{+} \\
\infty\end{array}$ & $\begin{array}{l}\vec{b} \\
\dot{0}\end{array}$ & $\stackrel{\overrightarrow{0}}{\stackrel{5}{0}}$ & $\begin{array}{c}\bar{n} \\
\stackrel{+}{0} \\
0\end{array}$ & 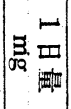 & 熟 \\
\hline \begin{tabular}{c}
$\mathscr{c}$ \\
\hdashline \\
$\infty$
\end{tabular} & $\begin{array}{l}\mathscr{\infty} \\
\stackrel{0}{0}\end{array}$ & $\stackrel{\infty}{\stackrel{\circ}{\circ}}$ & $\stackrel{\substack{\infty \\
:}}{=}$ & $\begin{array}{l}\text { or } \\
\text { or }\end{array}$ & $\stackrel{\infty}{\stackrel{\infty}{+}}$ & $\stackrel{\infty}{\stackrel{\infty}{+\infty}}$ & $\begin{array}{c}\infty \\
0 \\
0 \\
0\end{array}$ & $\begin{array}{l}\infty \\
\stackrel{0}{*} \\
-1\end{array}$ & $\begin{array}{l}\infty \\
\stackrel{0}{0} \\
\dot{\sigma o s}\end{array}$ & $\begin{array}{l}\infty \\
0 \\
0 \\
i 0\end{array} \mid$ & 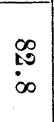 & $\begin{array}{l}\infty \\
: \\
0\end{array}$ & $\underset{\infty}{\stackrel{\infty}{\infty}}$ & $\begin{array}{l}\infty \\
0 \\
0 \\
0\end{array}$ & $\stackrel{\infty}{\stackrel{\infty}{+}}$ & $\begin{array}{l}\infty \\
\stackrel{\infty}{0} \\
\text { io }\end{array}$ & 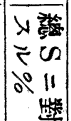 & 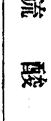 \\
\hline $\begin{array}{l}8 \\
8 \\
0\end{array}$ & $\begin{array}{l}\overrightarrow{5} \\
\text { is }\end{array}$ & $\dot{\infty}$ & $\begin{array}{l}\text { o } \\
\text { is }\end{array}$ & $\stackrel{ }{\circ}$ & $\begin{array}{l}\stackrel{0}{0} \\
\stackrel{-}{*}\end{array}$ & $\stackrel{10}{: 0}$ & $\stackrel{\stackrel{N}{:}}{: 0}$ & $\begin{array}{c}0 \\
0 \\
0\end{array}$ & $\begin{array}{l}10 \\
10 \\
0\end{array}$ & $\begin{array}{l}: \\
: \\
i v\end{array}$ & 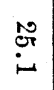 & $\begin{array}{c}\vec{\infty} \\
\dot{\sigma} \\
\vec{v}\end{array}$ & $\begin{array}{l}\text { ¿ै } \\
\text { oे }\end{array}$ & $\begin{array}{l}\stackrel{8}{8} \\
\dot{\omega}\end{array}$ & $\begin{array}{l}\overrightarrow{0} \\
\dot{\sigma}\end{array}$ & 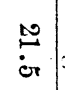 & $s_{30}^{-1}$ & F \\
\hline$\underset{\text { is }}{\vec{P}}$ & $\underset{\sim}{\vec{S}}$ & $\stackrel{\vec{P}}{\stackrel{5}{0}}$ & $\underset{\dot{c}}{\vec{p}}$ & 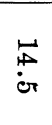 & $\overrightarrow{0}$ & $\stackrel{\overrightarrow{e r}}{\vec{v}}$ & $\overrightarrow{0}$ & $\begin{array}{l}\vec{J} \\
\dot{i}\end{array}$ & $\begin{array}{l}\vec{r} \\
\dot{\sigma o r}\end{array}$ & $\begin{array}{l}\overrightarrow{0} \\
\infty\end{array}$ & $\vec{T}$ & $\stackrel{\vec{F}}{\dot{0}}$ & $\underset{\text { is }}{\vec{F}}$ & 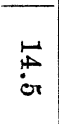 & $\begin{array}{c}\vec{c} \\
: 0 \\
0\end{array}$ & $\underset{\infty}{\stackrel{\vec{f}}{\infty}}$ & 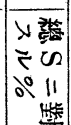 & 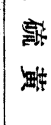 \\
\hline$\dot{\ddot{\sigma}}$ & $i_{\text {iv }}^{-1}$ & $\begin{array}{l}0 . \\
\dot{\phi}\end{array}$ & $\ddot{0}$ & $\begin{array}{l}\dot{\theta} \\
\dot{\rho}\end{array}$ & $\stackrel{\sigma}{\dot{\omega}}$ & $\dot{\mathrm{B}}$ & $\dot{P}_{\overrightarrow{10}}^{+1}$ & $\begin{array}{l}\ddot{\theta} \\
\dot{y}\end{array}$ & $\begin{array}{l}\dot{8} \\
\dot{8}\end{array}$ & 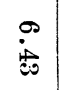 & $\stackrel{\infty}{\dot{\infty}}$ & $\begin{array}{l}0 \\
\dot{\dot{c}} \\
\end{array}$ & $\stackrel{-1}{: 0}$ & $\begin{array}{l}\overrightarrow{1} \\
\ddot{\infty}\end{array}$ & $\begin{array}{l}0 \\
0 \\
0\end{array}$ & $\stackrel{\dot{\sigma}}{\sigma}$ & $\underbrace{5}_{00} \frac{1}{\square}$ & H \\
\hline $\begin{array}{l}0 r \\
0\end{array}$ & or & $\stackrel{\vec{\theta}}{\dot{\theta}}$ & $\stackrel{\leftrightarrow}{0}$ & $\stackrel{+}{\infty}$ & $\stackrel{+}{\infty}$ & $\stackrel{\leftrightarrow}{\sim}$ & $\begin{array}{l}0 \pi \\
\dot{\theta}\end{array}$ & $\stackrel{0}{\sigma}$ & $\stackrel{+}{\sigma}$ & $\stackrel{+}{\sigma}$ & $\stackrel{+}{\sigma}$ & $\stackrel{+}{\stackrel{4}{*}}$ & $\stackrel{+}{0}$ & $\stackrel{0}{\sigma}$ & $\underset{i o}{+}$ & $\overrightarrow{i s}$ & 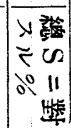 & $\frac{y}{y}$ \\
\hline \multirow[t]{2}{*}{$\begin{array}{l}1: \\
\mathscr{8} \\
\mathscr{8}\end{array}$} & $\begin{array}{l}10 \\
\infty \\
0 \\
0\end{array}$ & $\begin{array}{l}\circ \\
\stackrel{0}{\circ}\end{array}$ & 总 & $\begin{array}{l}10 \\
\stackrel{10}{8} \\
8 \\
8\end{array}$ & $\begin{array}{l}10 \\
\infty \\
0 \\
0\end{array}$ & $\begin{array}{l}\text { : } \\
\text { : }\end{array}$ & $\begin{array}{l}\text { to } \\
\ddot{E}\end{array}$ & $\begin{array}{l}10 \\
\stackrel{0}{\circ} \\
\stackrel{8}{8}\end{array}$ & 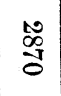 & $\begin{array}{l}1 \\
\infty \\
0 \\
0\end{array}$ & 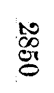 & $\begin{array}{l}10 \\
\stackrel{0}{\circ} \\
\stackrel{8}{\circ}\end{array}$ & $\begin{array}{l}10 \\
0 \\
0\end{array}$ & $\begin{array}{l}10 \\
0 \\
\mathbb{8}\end{array}$ & $\begin{array}{l}\text { Do } \\
\text { of } \\
0\end{array}$ & $\left|\begin{array}{l}1 \\
0 \\
0 \\
0\end{array}\right|$ & & \\
\hline & & & & & $\begin{array}{l}\stackrel{0}{0} \\
\dot{\rho}\end{array}$ & $\begin{array}{l}0 \\
\dot{0} \\
0 \\
0\end{array}$ & 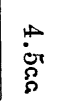 & 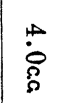 & 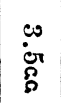 & $\begin{array}{l}0.0 \\
0 \\
0 \\
0\end{array}$ & 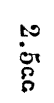 & & & & & & & \\
\hline
\end{tabular}




\begin{tabular}{|c|c|c|c|c|c|c|c|c|c|c|c|c|c|c|c|c|}
\hline \multicolumn{2}{|c|}{ 躍 } & \multicolumn{2}{|c|}{ 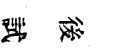 } & \multicolumn{3}{|c|}{ 造 } & \multicolumn{2}{|l|}{ 囉 } & \multicolumn{2}{|l|}{ 些 } & \multicolumn{2}{|c|}{ 虂 } & \multicolumn{2}{|c|}{ 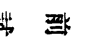 } & \multirow{2}{*}{\multicolumn{2}{|c|}{ 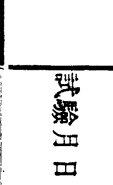 }} \\
\hline * & $\overrightarrow{0}$ & 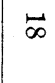 & $\vec{\sigma}$ & 5 & $\vec{c}$ & 实 & $\overrightarrow{c o}$ & to & $\Xi$ & 무 & 0 & $\infty$ & $-\rightarrow$ & $\stackrel{\mathscr{P}}{\forall}$ & & \\
\hline$\vec{\infty}$ & $\overrightarrow{8}$ & $\vec{\circ}$ & $\overrightarrow{8}$ & $\stackrel{10}{0}$ & $\vec{g}$ & $\vec{q}$ & $\overrightarrow{8}$ & $\overrightarrow{8}$ & $\overrightarrow{8}$ & $\tilde{8}$ & $\overrightarrow{\mathscr{o}}$ & $\vec{\phi}$ & $\overrightarrow{\&}$ & $\overrightarrow{8}$ & & 政 \\
\hline $\begin{array}{l}\vec{c} \\
\stackrel{0}{0} \\
\dot{i s}\end{array}$ & $\begin{array}{l}\overrightarrow{0.0} \\
\stackrel{0}{0} \\
0 \\
0\end{array}$ & $\begin{array}{l}r .0 \\
0.0 \\
0 \\
0 \\
0\end{array}$ & $\begin{array}{l}\overrightarrow{c o} \\
\text { o } \\
\dot{0}\end{array}$ & 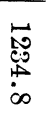 & $\begin{array}{l}\overrightarrow{0} \\
\stackrel{\circ}{0} \\
\dot{0}\end{array}$ & $\begin{array}{l}\overrightarrow{\vec{N}} \\
\stackrel{0}{0} \\
\stackrel{0}{i}\end{array}$ & 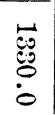 & $\begin{array}{l}\bar{F} \\
.0 \\
0 \\
0 \\
0 \\
0\end{array}$ & 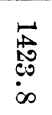 & $\begin{array}{l}\overrightarrow{9} \\
\stackrel{10}{10} \\
\stackrel{+}{0}\end{array}$ & 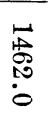 & $\begin{array}{l}\overrightarrow{c 0} \\
\stackrel{0}{0} \\
\stackrel{0}{0} \\
\dot{0}\end{array}$ & $\begin{array}{l}\text { 点 } \\
\stackrel{\infty}{\circ} \\
\infty\end{array}$ & $\frac{\text { 㕝 }}{\dot{0}}$ & & $\begin{array}{l}\text { 落 } \\
z\end{array}$ \\
\hline $\begin{array}{c}\vec{\bullet} \\
\stackrel{\overrightarrow{0}}{*} \\
\dot{0}\end{array}$ & 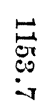 & 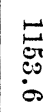 & 岑 & $\begin{array}{l}\overrightarrow{5} \\
\text { 15 } \\
0 \\
\text { or }\end{array}$ & $\begin{array}{l}\overrightarrow{0} \\
\stackrel{0}{0} \\
0\end{array}$ & $\begin{array}{l}\overrightarrow{5} \\
1 \\
\infty \\
i 0\end{array}$ & 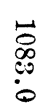 & 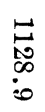 & 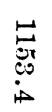 & $\begin{array}{l}\overrightarrow{\omega 0} \\
\vec{\sigma} \\
\dot{0}\end{array}$ & $\begin{array}{l}\overrightarrow{0} \\
\stackrel{8}{\$} \\
0\end{array}$ & $\begin{array}{l}\vec{\sigma} \\
\stackrel{0}{0} \\
0 \\
0\end{array}$ & $\begin{array}{l}\overrightarrow{10} \\
\text { जै } \\
\dot{0}\end{array}$ & $\begin{array}{l}\underset{0}{0} \\
\infty \\
0\end{array}$ & ${ }_{10}$ & 济 \\
\hline$\infty$ & $\stackrel{\infty}{\risingdotseq}$ & $\infty$ & $\mathbb{1}$ & 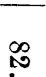 & $\infty$ & $\infty$ & $\stackrel{\infty}{\infty}$ & $\stackrel{\infty}{\bullet}$ & $\stackrel{\infty}{\bullet}$ & g & $\underset{\infty}{\infty}$ & $\stackrel{\infty}{\infty}$ & $\stackrel{\infty}{\stackrel{\infty}{\infty}}$ & $\begin{array}{l}\infty \\
10\end{array}$ & 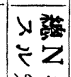 & 7 \\
\hline io & ì & ì & is & is & is & $\dot{8}$ & 虫 & 完 & $\dot{\rho}$ & $\dot{8}$ & $\ddot{g}$ & i் & $\dot{\theta}$ & is & 이 & \\
\hline$\ddot{0}$ & $\begin{array}{l}0 r \\
\dot{v}\end{array}$ & זٓ & 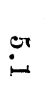 & $\stackrel{o}{\dot{o r}}$ & $\begin{array}{l}0 r \\
0\end{array}$ & $\begin{array}{l}e r \\
0\end{array}$ & $\underset{0}{0}$ & ن̈ & 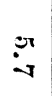 & $\begin{array}{l}\dot{0} \\
\dot{\sigma}\end{array}$ & $\begin{array}{l}\dot{0} \\
0 \\
0\end{array}$ & $\ddot{0}$ & $\ddot{0}$ & $\ddot{0}$ & $z_{00}$ & si \\
\hline $\begin{array}{l}0 \\
\dot{8} \\
\dot{\infty}\end{array}$ & $\stackrel{\dot{D}}{\dot{E}}$ & $\begin{array}{l}\dot{0} \\
\dot{\theta}\end{array}$ & 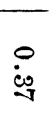 & $\begin{array}{l}0 \\
\text { ir } \\
\text { iv }\end{array}$ & $\begin{array}{l}\circ \\
\dot{\theta}\end{array}$ & $\begin{array}{l}0 \\
\dot{d i g}\end{array}$ & $\stackrel{\circ}{\stackrel{\phi}{+}}$ & $\stackrel{0}{\dot{\phi}}$ & $\stackrel{0}{\dot{0}}$ & $\begin{array}{c}0 \\
\dot{i} \\
\oplus\end{array}$ & $\stackrel{\circ}{i \infty}$ & $\stackrel{0}{\dot{\omega}}$ & $\begin{array}{l}0 \\
i \neq \\
i \neq\end{array}$ & $\begin{array}{l}0 \\
\dot{A}\end{array}$ & 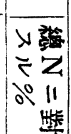 & $\equiv$ \\
\hline$\stackrel{\vec{\circ}}{ }$ & $\ddot{i}$ & $\vec{\circ}$ & $\overrightarrow{0}$ & 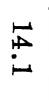 & $\vec{\sigma}$ & $\overrightarrow{\breve{r}}$ & $\stackrel{\vec{\infty}}{\dot{-}}$ & $\begin{array}{l}0 \\
: 00 \\
0 \\
0\end{array}$ & $\begin{array}{l}\stackrel{\mathscr{0}}{\circ} \\
\dot{1}\end{array}$ & $\begin{array}{l}00 \\
0 \\
\infty\end{array}$ & $\stackrel{\overrightarrow{0}}{\leftarrow}$ & is & $\vec{\sigma}$ & $\ddot{\circ}$ & 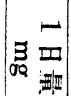 & Y \\
\hline $\begin{array}{l}0 \\
\dot{y}\end{array}$ & $\stackrel{\circ}{\stackrel{1}{1}}$ & $\stackrel{\circ}{\dot{c}}$ & $\stackrel{\circ}{\dot{\infty}}$ & 它 & $\overrightarrow{\dot{\theta}}$ & is & $\ddot{\dot{\phi}}$ & $\stackrel{\sim}{\dot{B}}$ & $\stackrel{\sim}{\dot{\infty}}$ & $\begin{array}{l}\text { 号 } \\
\text { 曽 }\end{array}$ & 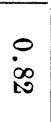 & $\stackrel{0}{-10}$ & $\stackrel{0}{8}$ & $\dot{8}$ & 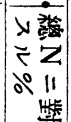 & 要 \\
\hline$\stackrel{\leftrightarrow}{\rightarrow}$ & $\begin{array}{l}e r \\
0\end{array}$ & $\stackrel{t}{c}$ & is & $\begin{array}{l}\text { or } \\
\text { is }\end{array}$ & 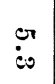 & $\begin{array}{l}\dot{c} \\
\dot{\sigma}\end{array}$ & $\dot{0}$ & $\stackrel{0}{0}$ & סे & $\ddot{0}$ & $\stackrel{\infty}{\infty}$ & $\stackrel{\oplus}{\dot{\sigma}}$ & $\stackrel{\leftrightarrow}{\dot{\theta}}$ & $\ddot{0}$ & ${ }_{00}^{\prime}=$ & 涪 \\
\hline $\begin{array}{l}0 \\
\dot{q u} \\
\dot{q}\end{array}$ & $\stackrel{\circ}{\stackrel{0}{0}}$ & $\begin{array}{l}\dot{0} \\
\dot{\phi}\end{array}$ & 过 & 足 & 总 & $\stackrel{0}{\dot{i}}$ & 苞 & $\underset{\text { i }}{\stackrel{0}{c}}$ & $\stackrel{0}{\dot{B}}$ & $\stackrel{0}{\dot{\leftrightarrow}}$ & 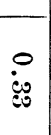 & : & 它 & 惫 & 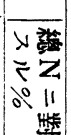 & $z$ \\
\hline $\begin{array}{l}0 \\
\dot{\leftrightarrow} \\
\dot{\infty}\end{array}$ & $\stackrel{\circ}{-}$ & 悹 & $\dot{\leftrightarrow}$ & $\stackrel{\circ}{\infty}$ & خे & $\begin{array}{l}\circ \\
\dot{3}\end{array}$ & $\dot{\circ}$ & $\dot{8}$ & $\stackrel{\circ}{\dot{0}}$ & $\dot{0}$ & $\stackrel{\circ}{\dot{d}}$ & $\begin{array}{l}0 \\
\dot{\leftrightarrow} \\
0\end{array}$ & $\dot{0}$ & $\dot{\circ}$ & $\frac{\pi}{10}$ & $\stackrel{\stackrel{\varphi}{\circ}}{=}$ \\
\hline$\dot{\circ}$ & $\stackrel{\circ}{\dot{G}}$ & $\dot{\phi}$ & $\dot{\circ}$ & $\dot{P}$ & $\dot{8}$ & $\dot{\dot{G}}$ & $\begin{array}{l}\dot{0} \\
\dot{\leftrightarrow}\end{array}$ & $\dot{\circ}$ & $\stackrel{\circ}{\circ}$ & $\stackrel{\circ}{\circ}$ & $\dot{\circ}$ & $\dot{8}$ & $\dot{\phi}$ & $\dot{\circ}$ & 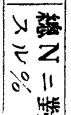 & 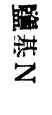 \\
\hline
\end{tabular}




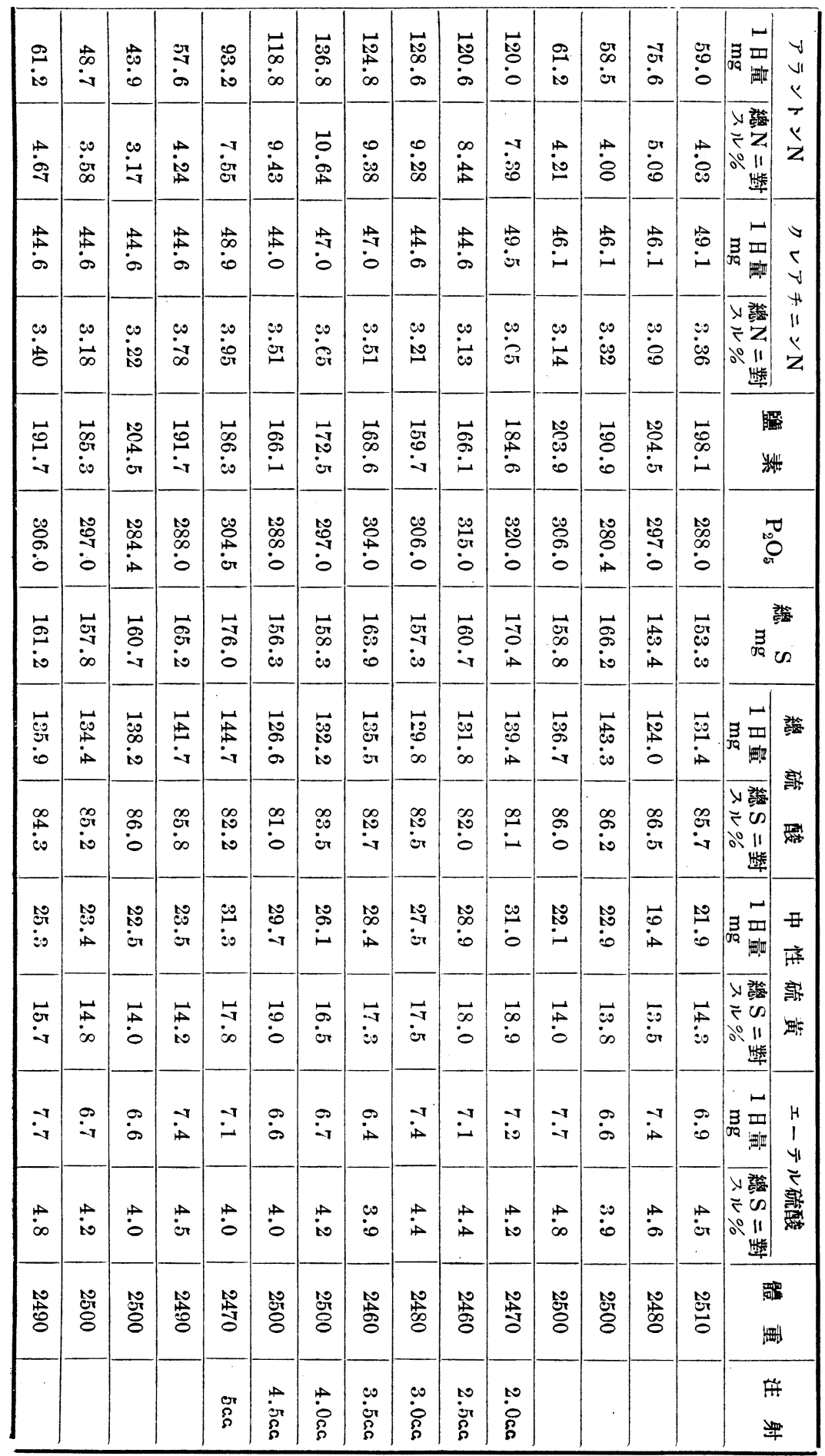


鼠素. 注射後㥛メテ僅微ノ減少

總燐酸. 僅少ノ增加アリ。( $8 \%)$

總硫黃. /排泄八注射ニヨリ僅カ二增ス二過ギザレドモ。硫黃化合物, 比率八著シ ク變化シ。中性硫黃量八增シ。硫酸量八減少ス。

第 3 實驗 (第 3 表)

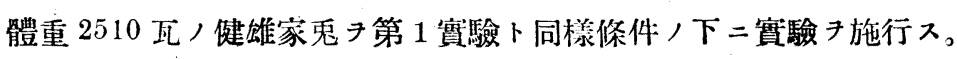

臨林的所見

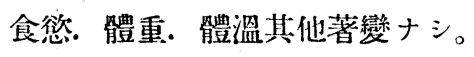

尿所見

尿量. 著變ナシ。

蛋白・糖檢査. 共二總テ㓌性ナリ。

尿總窒素量. 第 1 回注射後增加シ。第 2 回以後漸次低下スル事前成績卜同樣ナリ。

尿素塋素量. 前實驗卜同成績キ示ス。

安門突素量. 第 2 表卜同樣注射二俄儿變化著シカラズ。

Amino-酸器素量. 第 1 包注射後前試驗二比シテ約 3 倍强/增加テ示シ。增量注射卜 共二楜減シ約 $28 \%$ 增量二過ギズ. 注射中止後本常量二復ス。

尿酸空素量. 前 2 實驗卜殆ンド同樣ノ成績キ示ス。

Purin-監基紫素量. 變化著明ナラズ。

Allantoin-窒素量. 第 1 回注射二依リ約 2 倍二增加シ. 漸次增加シテ第 5 回注射後 最大增量二達ス，夫レョリ漱次低下ス，注射中止後八直チ二本常量二復セり。

Kreatinin-窒素量. 洼射二低ル變化認メズ。

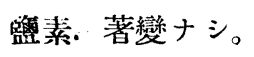

總燐酸. 僅少ノ增加于認メラル。(4\%)

總硫酸. 總硫黃二對ス几百分率八減少ス。

Äther-硫酸. 變化き認メズ。

中性硫黄. 稍、增加七り。(31\%)。

\section{第四童 總 括}

以上, 實驗き總括スレバ.

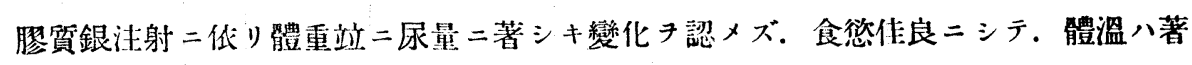
變ナシ．實驗中臨林的ニ八著シキ變化キ見ズ。 
尿所見

尿量. 著シキ增減ナシ。

總空素. 第 1 回注射後ニ於テ一時增加シ。其後注射尹繼續スルト雖モ直チ二本常二 復歸三。後漱次低娍入。

尿素案素. 第 1 回注射後絕對量八增加シ. 相對量八減少シ其後八絕對量八總紫素二 稍、本行シテ移動スルモ百分率八漸低ノ儘ナリ。

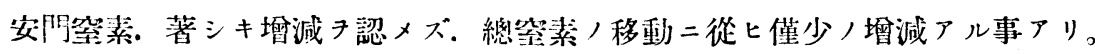

Amino-酸隹素. 注射後著シク增加三。第 1 回注射後約 3 倍內外，增加キ來タスモ.

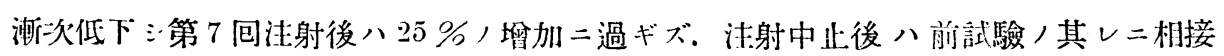
近不。

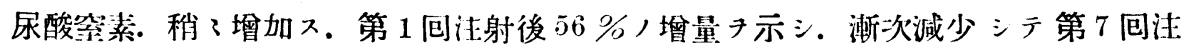
射後ハ $26 \%$ 增量尹示入．注射中止後八正常二復歸入。

Purin-監基. 稍了增加ス。

Allantoin-突菜. 顯著ナル增量き來タス。第 1 回注射後八其， $80 \%$ 增量シ.漸次 增加シテ第 $4-5$ 回二最高增加率 $126 \%$ 二涬入，以後漸次減少三第 7 回注射後 $=55 \%$ 增量入。汁射中止後前試驗，量二復入。

Kreatinin-等菜. 著シキ變化丹兒ズ，

監素. 本實驗二於テ多少ノ減少丹示ス。

總燐酸. 注射後ニハ一般二僅少，增量尹兒ル(7\%)。

總硫黃. 輕度ノ增量尹見. 其内總硫酸八可成減少シ. Äther-硫酸八極メテ微量，增 加アリ. えレニ反シ中性硫黃八 $34 \%$ /增加丹示ス。

\section{第五章 考 察}

飼料・飼養量及ビ採尿等丹同一條件二置キ. 實驗中二於テモ臨牀上(例へバ食慈. 體 重. 體溫等) 何等, 著シキ異常キ呈セザルニ依リ. 本常新陳代謝狀況卜銀注射後ノ新陳 代謝狀況尹比較シ得ベシ。殊二銀注射中止以後二於テ總テ正常二復歸スル所ヨリ見レ バ前記ノ制斷キ下スモ必ズシモ不當ナラズト信ズ。

1. 總窒素. 注射後一時排泄量，增加丹來タス八體蛋白質ノ分解旺盛ニナルキ示ス.

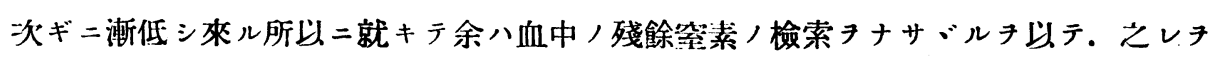

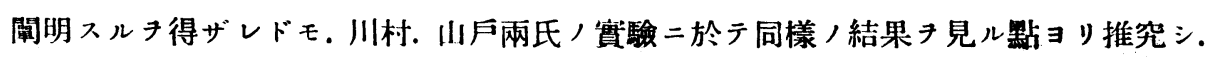
篦素量漸減二八何等力，意味キ有スルナラント想像シ得レドモ未来多明カナラズ。 


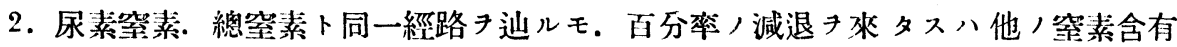
物質，多量排泄二依りテ來タス乎. 肝藏，合成機能減退二低りテ起ル乎. 或八合成材 料ノ缺乏二基因スル乎. 又八酸形成過剩二基ジク乎タ明カニセザル可カラズ。

酸形成過剩ニ低ルモノナラバ安門空素/增量キ來タス可キモ。余ノ成績八其所以 示サズ. 其他ノ三ッノ場合八尿素窒素百分率低減二多少八關係尹有ス儿事尹推察シ得 ベケレドモ。主ナル因八他，聜素排泄量，增加ニ低リテ以上，成績 表示スル如り想 像七ラル。

3. 安門窂素. 銀注射後著シキ增減キ示サズ．目、酸形成（總硫酸）モ絕對量ニ於テ 八余ハ著シカラズ。

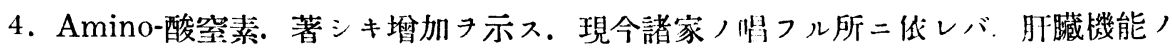
減退尹來タス場合二八. Amino-基, 脫離作用減退. 或ハ不完全ナル分解チナスキ以

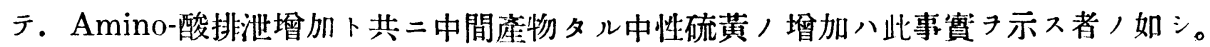

掔ツテ考フルニ。高橋, 四監化炭素中毒, 新陳代謝試驗二於テハAmino-酸等素量 八 10 倍ノ增加丹示七り。そレニ比シテ余ノ成績ニ於テ 3 倍, 增加八遙力二僅少ノ增 加二過ギズ況ンャ本實驗中. 注射連綡卜共二濑次減少シ. 第 7 问洼射後二八僅力二 $25 \%$ 增加二過ギザルニ於テョヤ。由是觀之. 膠質銀注射ニヨリ朋藏ヨ侵シタリトスル モ甚名輕微ニシテ. 直チ二恢復スルモノナランカ。

5. Purin-體. 尿酸及 Purin-監基八稍、增加スレドモ. Allantoin /增加八最モ顯 著ナリ. 一般ニ Purin-體, 增加ハ核蛋白質ノ分解, 盛ナル事キ意味スルモノナレバ. 余ノ實驗二於テ望質銀注射ニヨリ核細胞ノ破壞ヨ表示スルモノナリ。

白川八膠質銀 靜脈內或八皮下二洼射 シテ尿中總窒素. 尿酸. Allantoin-突素，增

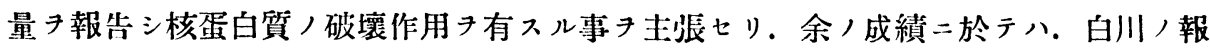
雀二比シテ Allantoin/增加特二著シキモノアリ. えレ或八白川卜. 余ノ用七タル定 量分法ノ相異ス江䉆二由ルナラン乎。

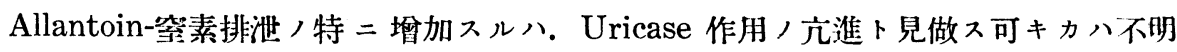
ナレドモ。注射物質或八分解物質ノ刺激ニ依ルモノナラン乎。

他方二肝臟機能輕度ノ減退 7 暗示スル. Amino 脫雄作用, 減弱 二. 肝臟, Uricase 作用充進二依ル Allantoin 形成ノ允進キ考フルハ不當ナル想像

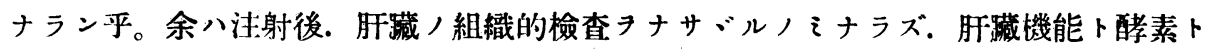

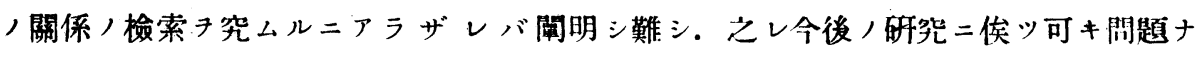
り。 


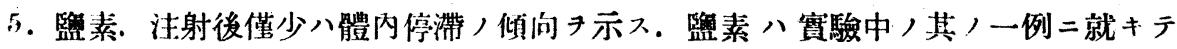
胃ル二前試驗中．㯺素量ハ $14 \%$ 動搖アリ．注射後其，減少量本均 $26 \%$ 示ス。

文監素ハ水分代謝二密接ナル關係尹有シ。内分泌腺二モ關聯セル問題二テ.今直チ ニ之レョ關明スル事難シ。

6. 總燐酸. 一般含哠酸蛋白質分解二本行シテ增減入. 注射後二於テ八增加ヲ示七 り核蛋白質分解二於テモ燐酸八增加スルモノナレバ。從ツテ Purin 體, 增加二モ相 伴フ事明カナリ。

7.總硫酸. 含硫蛋白質，分解ニヨリテ生ズル事明カナリ。余，實驗二於テハ酸形 成減退シ。中間成物ナル中性硫黃含有物增加七リ。之レ即千蛋白質，分解殊二核質， 分解旺盛ニシテ.シカモ其酸化八不完全ナル事. 即千蛋白質ノ中間新陳代謝異常キ示 त。

\section{第六章 結 論}

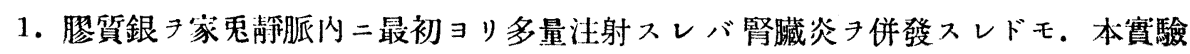

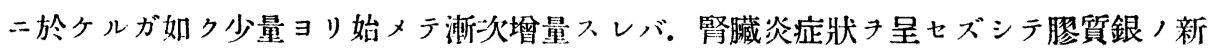
陳代謝ニ及ボス變化キ檢索スルニ八至便ナリ。

2. 本實驗 ニョリテ. 膠質銀，注射後二於テ．尿素排泄，百分率八減ジテ.Amino． 酸排泄, 增加テ兒ル。

3. 又 Purin-艠，排泄量著シク增加久. 就中 Allantoin，增加顯著ナリ. 此點ヨ リ洘察スレバ膠質銀八有核細胞, 破壞作用丹旺盛ナラシメ。シカモ肝臟機能二餘り障 碍子與へザルモ，、如シ。

4. 然レドモ Amino-酸排泄量, 增加程度ヨリ推七バ肝藏機能モ一過性二輕度, 障

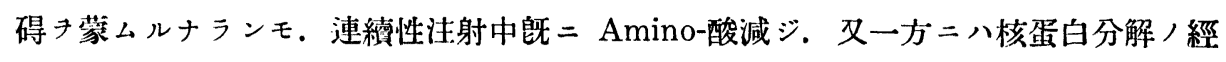
路二八異常キ示サズシテ. 其ノ最終產物タル Allantoin 形成能力ノ增進スル事ョリ 見レバ.其ノ肝藏機能障得モ輕度二シテ又後二徐々二恢復スルモノナラン。

5. 總硫酸, 量二比シテ中性硫黃, 增加スル事ヨり推定スレバ蛋白分解八旺盛ナレ ドモ其ノ經路二障碍アルモ, 、如シ。

6. 之レタ要スル二膠質銀 持續的二增量注射スル場合二八. 最初八蛋白質，異常分 解殊二核蛋白, 破壞作用起リ. 且ツ多少肝臟, 機能障碍アレドモ連續注射ナ行フ間二

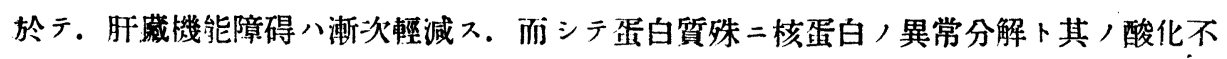
全ハ繼續スルモノナリ。 
終リ二臨々長與所長竝二林教授二敬意丹表シ。終始御愍篤ナル御指導卜御鞭鞋卜タ 賜リ且ツ御校閲ノ勞キ取ラレタル河本敎授二深甚ノ謝意キ表ス。

\section{圭要文糔}

1) E. Abderhalden, Lehrbuch d. physiologischen. Chemie. (1923). 2) I. Bang, Lehrbuch

d. Harnanalyse. 3) F. Blumenthal, Handbuch d. Spec. Pathologie d. Harns. (1913). 4) Brugsch u. Schittenhelm, Technik u. Spec. Klin. Untersuch. Methode. 5) O. Hammarsten, Lehrbuch d. physiologischen Chemie. (1926). 6) 七樂虎雄, 實驗醫學雜誌. 第 9 卷. 第 12 號. 7) 柿內三郎, 生化學提要. 8) 加藤安太郎, 福岡醫科大學雜誌. 第 19 卷. 第 1 號. 9) 木村辰夫, The Journal of Biochemistry Vol. VIII. No. 2. 10) Neubauer-Huppert,

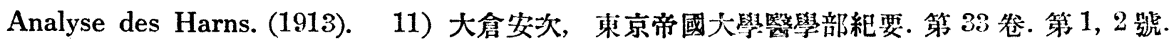
12) C. Oppenheimer, Biochemie. (1925). 13) Pincussen, Mikromethodik. 1925. 14) 須藤憲三，小繄化學實柏. 第 13 版. 15) 白川彌源太, 未發表. 16) 高橋盈, 實驗醫學雑 誌. 第 13 卷. 第 10 號. 17) E. Willian Peterson, Proteintherapie u. unspec. Leitungsteigerung. (1923). 